\title{
Alcohol: Effects on Nutritional Status, Lipid Profile and Blood Pressure
}

\author{
Mayla Cardoso Fernandes Toffolo ${ }^{\mathrm{a}}$, Aline Silva de Aguiar-Nemer ${ }^{\mathrm{a}, \mathrm{c}}$, \\ Vilma Aparecida da Silva-Fonseca ${ }^{\mathrm{b}}$
}

\begin{abstract}
Alcohol consumption can be the cause of several diseases. Depending on the frequency and quantity, the consumption of alcohol may increase the risk of malnutrition, weight-gain, obesity and cardiovascular diseases. The aim of this study was to review the influence of alcohol intake on nutritional status, lipid profile and blood pressure. The review shows that the additional consumption of ethanol calories will favor weight gain and metabolic changes and may engrave the risk of cardiovascular diseases, altering the lipid profile and promoting hypertension. Recommending a moderate use of alcohol with the purpose of taking advantage of its health benefits must not be done.
\end{abstract}

Keywords: Nutritional status; Obesity; Ethanol; Cardiovascular disease

\section{Introduction}

Alcohol consumption can be the cause of several diseases, and it is, well known, the high burden of its consumption over mortality around the world [1]. Alcohol is the only psychoactive drug that provides energy $(7.1 \mathrm{kcal} / \mathrm{g})$. However, alcohol intake can increase the risk of weight-gain and the development of obesity or malnutrition. Additionally, the

\footnotetext{
Manuscript accepted for publication October 12, 2012

aDepartamento de Nutrição, Instituto de Ciências Biológicas, Universidade Federal de Juiz de Fora, Juiz de Fora, Minas Gerais, Brasil

${ }^{b}$ Nucleo de Ciencias Comportamentais e do Desenvolvimento, Departamento de Fisiologia e Farmacologia, Instituto Biomedico, Universidade Federal Fluminense, Rio de Janeiro, Brasil

${ }^{\mathrm{c}}$ Corresponding author: Aline Silva de Aguiar Nemer, Universidade Federal de Juiz de Fora, Instituto de Ciencias Biologicas, Departamento de Nutricao, Cidade Universitaria/Juiz de Fora, Minas Gerais, Brasil. Email: aline.nemer@ufjf.edu.br
}

doi: http://dx.doi.org/10.4021/jem128e frequency and quantity in which alcoholic beverages are consumed are important factors that should be included in the evaluation of the risk for cardiovascular diseases.

Nutritional effects of alcohol are entangled with cardiovascular toxicity and there are many aspects to review on the subject. Depending on the age of the subject, its previous nutritional state, and dose of alcohol ingestion, the consumption of alcohol can lead to different and opposite effects. For these reason, the aim of this study was to review the influence of alcohol intake on nutritional status and the consequent effects on the lipid profile and hypertension.

\section{Alcohol and Malnutrition}

Alcohol is the only psychoactive drug that provides energy $(7.1 \mathrm{kcal} / \mathrm{g})$. This drug is an intermediate source of energy when compared to proteins and carbohydrates, which provide $4.0 \mathrm{kcal} / \mathrm{g}$, and to the lipids, which provide $9.0 \mathrm{kcal} / \mathrm{g}$ [2]. However, its calories are considered "empty," because alcohol ingestion does not provide vitamins and minerals [3] and its use may cause alterations to the nutritional state [4].

Due to the high energy value of alcohol, it is common to assume that, when consumed in excess, alcohol increases the risk of weight-gain and the development of obesity [5]. However, despite its high calorie density, alcohol consumers do not appear to gain weight when compared to non-consumers [6].

When the alcohol caloric ingestion represents $50 \%$ or more of the total calorie ingestion, the body system may inefficiently utilize the energy provided by the ethanol ingestion due to the activation of the Microsomal Ethanol Oxidizing System (MEOS) [7]. At the cost of energy waste, the MEOS is the main liver pathway for ethanol oxidation [8]. Its induction is reversible after alcohol abstinence [9]. During the observational study of 181 hospitalized males that consumed more than $80 \mathrm{~g} /$ day of ethanol, Santolaria et al [10] observed that $63.1 \%$ suffered from anorexia, $58.7 \%$ presented weight loss, and $17.8 \%$ had a BMI below $20 \mathrm{~kg} / \mathrm{m}^{2}$. After a period of three months of alcohol abstinence, the use of caloric energy in alcoholics was normalized, just as the increase of the Body Mass Index (BMI) and the Waist Hip 
Ratio (WHP) [11]. The authors suggested the improvement in the nutritional state during abstinence may have occurred due to a less active MEOS, decreasing the waste of caloric energy.

Alcoholic patients presented metabolic and nutritional disorders due to alcohol consumption, and showed a high use of energy at a resting state [12], preferential use of lipids as energy source [13], and a 19\% reduction of the adipose tissue when compared to a healthy control group [14]. Cohort studies have shown that women who consume alcohol at a small or moderate rate (up to $30 \mathrm{~g} /$ day) have a lower risk to gain weight and become obese than those who abstain from it $[15,16]$, while other studies have reached the same conclusion regardless of the subjects' gender [17, 18].

Martin-Gonzalez et al [19] evaluated the prognostic value of the long-term alterations to the adipose and muscular tissues of alcoholics and the effects of abstinence on these changes. The results demonstrate that a loss of lean body mass during the first six months after the first evaluation is associated to a worse prognosis, whether or not patients were abstinent during this same period. However, non-abstinence was greater associated to the loss of lean body mass.

The energy derived from the intake of alcoholic beverages may be added to the diet of those with a moderate consumption of alcohol or may become a substitute to other foods to chronic consumers [18] possibly decreasing the gain of body mass, while increasing alcohol's toxicity [2]. Therefore, the body's use of ethanol calories may be associated with the dosage of alcohol. The consumption of alcohol dosages below $25-35 \%$ of the daily calories may be utilized as an energy source; however, at higher consumption, the utilization may not be complete [20].

In humans, caloric malnutrition is a close reality to millions of people dying of hunger around the world and, due to low prices and high availability, ethanol is ingested in place of food. Animal models were created in order to clarify what happens when a malnourished organism is exposed to ethanol. However, results were not what one would have expected. In fact, in low doses, alcohol consumption represents an important source of calories, mitigating the effects of malnutrition. Animal studies show that the consumption of low to moderate doses of alcohol (up to $20 \%$ of total caloric intake) causes weight gain in malnourished rats, which suggests an effective utilization of alcohol energetic content. Eutrophic rats, however, lose weight when the energetic content of alcohol represents $10 \%$ or more of the total calorie intake [21, 22].

\section{Could Alcohol be a Risk Factor for Obesity?}

The nutritional state of an individual may influence the utilization of the energy derived from alcoholic beverages. It is possible that, in humans, lean individuals have a more inef- ficient utilization of ethanol calories, and that in obese individuals the calories contribute to an increase of body mass [23].

Although prospective studies have defended a positive $[24,25]$ or negative $[26,27]$ correlations between alcohol consumption and obesity, a 10-year long prospective study showed that alcohol consumers had a more stable weight than non-consumers, indicating that alcohol consumption is not a risk factor for obesity [28]. Romeo et al [29] verified that a chronic and moderate monthly consumption of beer did not modify the weight or the body composition of adult individuals.

The impact of alcohol drinks over body weight continues to be a controversial topic, as results vary, showing sometimes an inverse (or negative) correlation between alcohol quantity and the BMI or the weight gain in women $[15,28,30-38]$ and, other times, a positive correlation [39, 40]. Moreover, studies found a positive association among men, [30, 39-48] as well as an inverse association [34, 36]. Actually, some studies, in both men [49] and women [35, 47], found no associations. Different patterns of consumption may be related to different outcomes [50].

Population studies demonstrate that the increase of body and abdominal fat is related to a moderate $[49,51]$ and frequent [52] alcohol consumption. There is also evidence that the alcohol can result in weight gain in different patterns to drink. The consumption of $\geq 30 \mathrm{~g}$ of alcohol/day may alter the balance of the energetic homeostasis, prompting an appetite increase and, consequently, body weight gain [53] and obesity, regardless of type of beverage consumed [43].

On a short-term, alcohol consumption is considered an appetite stimulant, influencing neurochemical and peripheral systems utilized to control appetite, such as, leptin inhibition, glucagon-like-peptide-1 and serotonin, and enhancing the effect of gamma-aminobutyric acid, endogenous opioids and neuropeptide Y. [54, 55] Hence, greater alcohol consumption with an absence of dependency, as well as binge drinking, may increase the risk for obesity. These effects may not be related to preferences for habitual drinks [56]. Toniolo et al [57] reported the increase of non-alcoholic energy consumption when an increase in the alcohol consumption was observed. However, Veenstra et al [58] showed that alcohol consumers and non-consumers had a similar intake of nonalcoholic caloric energy.

The association of alcohol consumption with a change in body weight and its development into obesity appears to be different depending on gender. Men add alcohol to the daily ingestion of calories, while women have a tendency to use alcohol as a substitute to other energy sources [30,59], such as reducing the consumption of carbohydrates $[16,18]$ without an increase of the total calorie ingestion. These differences must be included when considering the energetic balance, as they may generate different results regarding bodyweight.

A variety of obesity risk factors are related to alcohol 
consumption, such increased abdominal fat [60] decreased capability to oxidize lipids, consumption of high density calories diets [61, 62] and increase in cortisol secretion [63]. One may say that calories from alcohol are more utilized in individuals who are overweight or obese, and non-daily moderate consumers, than in those that are alcoholics and in a diet rich in fat [64].

Higher values of body, abdominal, and peripheral fat were also found in female, alcohol consumers, college students, showing a positive correlation between higher points in the AUDIT questionnaire and the BMI, the percentage of body fat, the waist circumference, the triceps skinfolds, and the arm circumference [65].

A study based on the data of the National Health Interview Surveys 1997 - 2001 demonstrated strong opposite effect between the quantity and frequency of alcohol consumption as related to the BMI. Individuals who drank more often but in small quantities (i.e. a drink a day, every day) had a lower BMI. On the other hand, individuals that drank less often, but did so in greater quantities (binge drinking), presented a higher BMI [39].

Jin et al [66] found an increase of the abdominal obesity risk factor in those individuals consuming $\geq 50 \mathrm{~g} /$ day. In agreement to this finding, in a study conducted with British individuals, it was noted that a consumption of $30 \mathrm{~g}$ or more of ethanol increased the risk of a high BMI and weight gain [43].

Similarly, the results provided after a study of the data of the Third National Health and Nutrition Examination Survey showed a lower chance of obesity among current alcohol consumers in relation to those abstinent, and a greater chance of obesity among binge drinking individuals or those who consume four or more doses a day. Obesity risk-factors were significantly lower among those reported drinking frequently but consuming less than five doses per week [40].

\section{Alcohol and Lipid Profile}

Alcohol consumption three to four days a week is associated with a lower risk of myocardial infarct among men and women. It is estimated that the cardio protector effect of alcohol may be attributed to $50 \%$ of the HDL-c increase [67, 68]. Moderate consumption of alcohol results (30 g ethanol/ day) increases the concentration of HDL-c in approximately $4 \mathrm{mg} / \mathrm{dL}$, and apoA-I in $8.82 \mathrm{mg} / \mathrm{dL}$, with a reduction to the risk of cardiac disease estimated at $24.7 \%$ [69, 70]. This alteration may occur despite the quantity or type of drink consumed (wine, spirits or beer) [71, 72]. Furthermore, alcohol promotes less degradation of HDL-c and a greater liver metabolism of LDL-c [72].

Although alcohol consumption induces alterations to the lipid profile and reduces cardiovascular events, the incidence of strokes, such as brain hemorrhages and subarachnoid hemorrhage, has shown to be more elevated in heavy drinkers than in those who do not consume alcohol [73]. Additionally, there is a progressive increase of diseases attributed to greater alcohol consumption [74], such as diabetes mellitus, hypertensive cardiac disease, ischemic heart disease, ischemic and hemorrhagic stroke, among others [75].

The variation between alcohol's risks and benefits are unique to each individual and its utilization as a tool to cardiovascular protection should not be encouraged as a public health measure [76]. Filmore et al [77] described the reduction of the alcohol benefits to the prevention of coronary disease in a meta-analysis study where abstemious and light and moderate alcohol consumers show the same risk of any death caused by coronary disease.

Recently, Chen et al [78] found high levels of triglycerides in individuals consuming $10 \mathrm{~g} /$ day of alcohol. Consumption greater than $50 \mathrm{~g} /$ day significantly reduced the risk of developing low levels of HDL-c, but elevated the risks of developing high levels of cholesterol.

In the post-prandial period, the alcohol is responsible for an increase in the triglycerides, with the inhibition of the oxidation of free fat acids (FFA) [79]. It is important to highlight that individuals with coronary disease, the post-prandial hypertriglyceridemia is greater and longer [80]. The hypertriglyceridemia or the increase of FFA are associated to a reduction of the endothelial vasodilation in normal individuals [81] and those who are insulin-resistant [82].

\section{Alcohol and Hypertension}

The alcohol intake elevates the arterial pressure in a dose-dependent response. Consumption higher than two daily doses is one of the most common reversible causes of hypertension [83]. The renin-angiotensin system might be involved in the mechanisms that alcohol to induce hypertension [84].

A study showed that the acute alcohol intoxication changed the renin-aldosterone system to humans with normal hydric and sodium balances. The increase plasma renin was, probably, caused by dehydration due to ethanol diuresis or to the inhibiting action of the ethanol in the aldosterone secretion [85]. No significative change was found in the osmolarity, arterial pressure, and cardiac frequency. Later, an acute increase of renin activity when there is a moderate ingestion of alcohol was confirmed, inducing changes to the fluid and electrolyte balance and arterial blood pressure [86].

However, the answer to a low and moderate consumption of alcohol seems to be different, depending on the individual's gender. Again, the literature is not in agreement about the question. In a prospective study developed by the Women's Health Study with 28,848 women and in another one developed by the Physicians' Health Study with 13,455, the low and moderate consumption of alcohol decreased the risk of hypertension in women and increased it in men. The 
threshold value above which alcohol became a risk factor for hypertension was equal to or larger than four doses a day in women versus a moderate level equal to or larger than one a day for men [87]. Nevertheless, some studies have been controversial when considering whether or not the arterial blood pressure sensitivity to alcohol is different in men and women [87-93].

Wakabayashi [94] suggests that an increase of the arterial blood pressure, as a consequence to habitual alcohol consumption, is more prominent in individuals with low body weight than in those with an elevated bodyweight. Therefore, the recommended alcohol consumption limit for the prevention of hypertension must be lower in women with low bodyweight than in those with a high bodyweight.

Stranges et al [95] investigated the association of alcohol consumption and the current drinking standards to the hypertension risk in healthy men and women without other cardiovascular diseases. When compared to abstemious, those who report alcohol drinks consumption had a higher risk of developing hypertension, despite the quantity of alcohol consumed.

A reduction in the ingestion of alcohol between heavy consumers significantly reduces the systolic and diastolic arterial pressures. Therefore, the reduction of alcohol consumption must be recommended as a life-style modification measure for the prevention and treatment of hypertension in heavy drinkers [96].

\section{Conclusion}

Alcohol is a drug of complex physiological effects that vary according to gender, age, race, body weight and consumption patterns. Recommending a moderate use of alcohol with the purpose of taking advantage of its health benefits must not be done. It must be reminded that there are groups of increased susceptibility to alcohol exposure. The present review shows that the additional consumption of ethanol calories will promote metabolic changes and weight gain increasing the risk of cardiovascular diseases, altering the lipid profile and promoting hypertension.

\section{References}

1. World Health Organization.(WHO). Global status report on alcohol and health. 2011; Available at: http://www. who.int/substance_abuse/publications/global_alcohol_ report/msbgsruprofiles.pdf. Acessed May 2012.

2. Aguiar AV. The medical marketing audit: technique for today's competitive extended care environment. Health Mark Q. 1984;1(4):45-50.

3. Molina PE, Hoek JB, Nelson S, Guidot DM, Lang $\mathrm{CH}$, Wands JR, Crawford JM. Mechanisms of al- cohol-induced tissue injury. Alcohol Clin Exp Res. 2003;27(3):563-575.

4. Lieber CS. Medical disorders of alcoholism. N Engl J Med. 1995;333(16):1058-1065.

5. Wakabayashi I. Impact of body weight on the relationship between alcohol intake and blood pressure. Alcohol Alcohol. 2009;44(2):204-210.

6. Jequier E. Alcohol intake and body weight: a paradox. Am J Clin Nutr. 1999;69(2):173-174.

7. Lands WE, Zakhari S. The case of the missing calories. Am J Clin Nutr. 1991;54(1):47-48.

8. Lieber CS. The influence of alcohol on nutritional status. Nutr Rev. 1988;46(7):241-254.

9. Hetu C, Joly JG. Differences in the duration of the enhancement of liver mixed-function oxidase activities in ethanol-fed rats after withdrawal. Biochem Pharmacol. 1985;34(8):1211-1216.

10. Santolaria F, Perez-Manzano JL, Milena A, GonzalezReimers E, Gomez-Rodriguez MA, Martinez-Riera A, Aleman-Valls MR, et al. Nutritional assessment in alcoholic patients. Its relationship with alcoholic intake, feeding habits, organic complications and social problems. Drug Alcohol Depend. 2000;59(3):295-304.

11. Addolorato G, Capristo E, Greco AV, Caputo F, Stefanini GF, Gasbarrini G. Three months of abstinence from alcohol normalizes energy expenditure and substrate oxidation in alcoholics: a longitudinal study. Am J Gastroenterol. 1998;93(12):2476-2481.

12. Addolorato G, Capristo E, Greco AV, Stefanini GF, Gasbarrini G. Energy expenditure, substrate oxidation, and body composition in subjects with chronic alcoholism: new findings from metabolic assessment. Alcohol Clin Exp Res. 1997;21(6):962-967.

13. Addolorato G, Capristo E, Greco AV, Stefanini GF, Gasbarrini $G$. Influence of chronic alcohol abuse on body weight and energy metabolism: is excess ethanol consumption a risk factor for obesity or malnutrition? J Intern Med. 1998;244(5):387-395.

14. Addolorato G, Capristo E, Marini M, Santini P, Scognamiglio U, Attilia ML, Messineo D, et al. Body composition changes induced by chronic ethanol abuse: evaluation by dual energy X-ray absorptiometry. Am J Gastroenterol. 2000;95(9):2323-2327.

15. Wannamethee SG, Field AE, Colditz GA, Rimm EB. Alcohol intake and 8-year weight gain in women: a prospective study. Obes Res. 2004;12(9):1386-1396.

16. Wang L, Lee IM, Manson JE, Buring JE, Sesso HD. Alcohol consumption, weight gain, and risk of becoming overweight in middle-aged and older women. Arch Intern Med. 2010;170(5):453-461.

17. Jones BR, Barrett-Connor E, Criqui MH, Holdbrook MJ. A community study of calorie and nutrient intake in drinkers and nondrinkers of alcohol. Am J Clin Nutr. 1982;35(1):135-139. 
18. Gruchow HW, Sobocinski KA, Barboriak JJ, Scheller JG. Alcohol consumption, nutrient intake and relative body weight among US adults. Am J Clin Nutr. 1985;42(2):289-295.

19. Martin-Gonzalez C, Gonzalez-Reimers E, SantolariaFernandez F, Fernandez-Rodriguez C, Garcia-Valdecasas-Campelo E, Gonzalez Diaz A, Alvisa-Negrin J, et al. Prognostic value of changes in lean and fat mass in alcoholics. Clin Nutr. 2011;30(6):822-830.

20. Mitchell MC, Herlong HF. Alcohol and nutrition: caloric value, bioenergetics, and relationship to liver damage. Annu Rev Nutr. 1986;6:457-474.

21. Aguiar AS, Da-Silva VA, Boaventura GT. Can calories from ethanol contribute to body weight preservation by malnourished rats? Braz J Med Biol Res. 2004;37(6):841-846.

22. Aguiar AS, Abrahao RF, Freitas TL, da Silva VA. Early malnutrition favours heavy ethanol intake in weaning rats without long-lasting effects. Nutr Neurosci. 2009;12(2):65-72.

23. Clevidence BA, Taylor PR, Campbell WS, Judd JT. Lean and heavy women may not use energy from alcohol with equal efficiency. J Nutr. 1995;125(10):2536-2540.

24. Gordon T, Kannel WB. Drinking and its relation to smoking, BP, blood lipids, and uric acid. The Framingham study. Arch Intern Med. 1983;143(7):1366-1374.

25. Gordon T, Doyle JT. Alcohol consumption and its relationship to smoking, weight, blood pressure, and blood lipids. The Albany Study. Arch Intern Med. 1986;146(2):262-265.

26. Camargo CA, Jr., Vranizan KM, Dreon DM, Frey-Hewitt B, Wood PD. Alcohol, calorie intake, and adiposity in overweight men. J Am Coll Nutr. 1987;6(3):271-278.

27. Cooke KM, Frost GW, Thornell IR, Stokes GS. Alcohol consumption and blood pressure: survey of the relationship at a health-screening clinic. Med J Aust. 1982;1(2):65-69.

28. Liu S, Serdula MK, Williamson DF, Mokdad AH, Byers T. A prospective study of alcohol intake and change in body weight among US adults. Am J Epidemiol. 1994;140(10):912-920.

29. Romeo J, Gonzalez-Gross M, Warnberg J, Diaz LE, Marcos A. [Does beer have an impact on weight gain? Effects of moderate beer consumption on body composition]. Nutr Hosp. 2007;22(2):223-228.

30. Colditz GA, Giovannucci E, Rimm EB, Stampfer MJ, Rosner B, Speizer FE, Gordis E, et al. Alcohol intake in relation to diet and obesity in women and men. Am J Clin Nutr. 1991;54(1):49-55

31. Hellerstedt WL, Jeffery RW, Murray DM. The association between alcohol intake and adiposity in the general population. Am J Epidemiol. 1990;132(4):594-611.

32. Dallongeville J, Marecaux N, Ducimetiere P, Ferrieres J, Arveiler D, Bingham A, Ruidavets JB, et al. Influ- ence of alcohol consumption and various beverages on waist girth and waist-to-hip ratio in a sample of French men and women. Int $\mathrm{J}$ Obes Relat Metab Disord. 1998;22(12):1178-1183.

33. Ruf T, Nagel G, Altenburg HP, Miller AB, Thorand B. Food and nutrient intake, anthropometric measurements and smoking according to alcohol consumption in the EPIC Heidelberg study. Ann Nutr Metab. 2005;49(1):1625.

34. Rohrer JE, Rohland BM, Denison A, Way A. Frequency of alcohol use and obesity in community medicine patients. BMC Fam Pract. 2005;6(1):17.

35. French MT, Norton EC, Fang H, Maclean JC. Alcohol consumption and body weight. Health Econ. 2010;19(7):814-832.

36. Gearhardt AN, Corbin WR. Body mass index and alcohol consumption: family history of alcoholism as a moderator. Psychol Addict Behav. 2009;23(2):216-225.

37. Sherwood NE, Jeffery RW, French SA, Hannan PJ, Murray DM. Predictors of weight gain in the Pound of Prevention study. Int $\mathrm{J}$ Obes Relat Metab Disord. 2000;24(4):395-403.

38. Skrzypczak M, Szwed A, Pawlinska-Chmara R, Skrzypulec V. Body mass index, waist to hip ratio and waist/ height in adult Polish women in relation to their education, place of residence, smoking and alcohol consumption. Homo. 2008;59(4):329-342.

39. Breslow RA, Smothers BA. Drinking patterns and body mass index in never smokers: National Health Interview Survey, 1997-2001. Am J Epidemiol. 2005;161(4):368376.

40. Arif AA, Rohrer JE. Patterns of alcohol drinking and its association with obesity: data from the Third National Health and Nutrition Examination Survey, 1988-1994. BMC Public Health. 2005;5:126.

41. Prentice AM. Alcohol and obesity. Int J Obes Relat Metab Disord. 1995;19 Suppl 5:S44-50.

42. Schroder H, Morales-Molina JA, Bermejo S, Barral D, Mandoli ES, Grau M, Guxens M, et al. Relationship of abdominal obesity with alcohol consumption at population scale. Eur J Nutr. 2007;46(7):369-376.

43. Wannamethee SG, Shaper AG. Alcohol, body weight, and weight gain in middle-aged men. Am J Clin Nutr. 2003;77(5):1312-1317.

44. Lahti-Koski M, Pietinen P, Heliovaara M, Vartiainen E. Associations of body mass index and obesity with physical activity, food choices, alcohol intake, and smoking in the 1982-1997 FINRISK Studies. Am J Clin Nutr. 2002;75(5):809-817.

45. Wannamethee SG, Shaper AG, Whincup PH. Alcohol and adiposity: effects of quantity and type of drink and time relation with meals. Int J Obes (Lond). 2005;29(12):1436-1444

46. Sung KC, Kim SH, Reaven GM. Relationship among 
alcohol, body weight, and cardiovascular risk factors in 27,030 Korean men. Diabetes Care. 2007;30(10):26902694.

47. Alcacera MA, Marques-Lopes I, Fajo-Pascual M, Puzo J, Blas Perez J, Bes-Rastrollo M, Martinez-Gonzalez MA. Lifestyle factors associated with BMI in a Spanish graduate population: the SUN Study. Obes Facts. 2008;1(2):80-87.

48. Lukasiewicz E, Mennen LI, Bertrais S, Arnault N, Preziosi P, Galan P, Hercberg S. Alcohol intake in relation to body mass index and waist-to-hip ratio: the importance of type of alcoholic beverage. Public Health Nutr. 2005;8(3):315-320.

49. Tolstrup JS, Heitmann BL, Tjonneland AM, Overvad OK, Sorensen TI, Gronbaek MN. The relation between drinking pattern and body mass index and waist and hip circumference. Int J Obes (Lond). 2005;29(5):490-497.

50. Sayon-Orea C, Martinez-Gonzalez MA, Bes-Rastrollo M. Alcohol consumption and body weight: a systematic review. Nutr Rev. 2011;69(8):419-431.

51. Dorn JM, Hovey K, Muti P, Freudenheim JL, Russell M, Nochajski TH, Trevisan M. Alcohol drinking patterns differentially affect central adiposity as measured by abdominal height in women and men. J Nutr. 2003;133(8):2655-2662.

52. Tolstrup JS, Halkjaer J, Heitmann BL, Tjonneland AM, Overvad K, Sorensen TI, Gronbaek MN. Alcohol drinking frequency in relation to subsequent changes in waist circumference. Am J Clin Nutr. 2008;87(4):957-963.

53. Navarro FB, Costa FD, Mulinari LA, Pimentel GK, Roderjan JG, Vieira ED, Noronha L, et al. Evaluation of the biological behavior of decellularized pulmonary homografts: an experimental sheep model. Rev Bras Cir Cardiovasc. 2010;25(3):377-387.

54. Yeomans MR, Caton S, Hetherington MM. Alcohol and food intake. Curr Opin Clin Nutr Metab Care. 2003;6(6):639-644.

55. Yeomans MR. Effects of alcohol on food and energy intake in human subjects: evidence for passive and active over-consumption of energy. Br J Nutr. 2004;92 Suppl 1:S31-34.

56. Yeomans MR. Alcohol, appetite and energy balance: is alcohol intake a risk factor for obesity? Physiol Behav. 2010;100(1):82-89.

57. Toniolo P, Riboli E, Cappa AP. A community study of alcohol consumption and dietary habits in middle-aged Italian women. Int J Epidemiol. 1991;20(3):663-670.

58. Veenstra J, Schenkel JA, van Erp-Baart AM, Brants HA, Hulshof KF, Kistemaker C, Schaafsma G, et al. Alcohol consumption in relation to food intake and smoking habits in the Dutch National Food Consumption Survey. Eur J Clin Nutr. 1993;47(7):482-489.

59. Yung L, Gordis E, Holt J. Dietary choices and likelihood of abstinence among alcoholic patients in an outpatient clinic. Drug Alcohol Depend. 1983;12(4):355-362.

60. Rissanen AM, Heliovaara M, Knekt P, Reunanen A, Aromaa A. Determinants of weight gain and overweight in adult Finns. Eur J Clin Nutr. 1991;45(9):419-430.

61. Kachani AT, Brasiliano S, Hochgraf PB. O impacto do consumo alcoolico no ganho de peso. Rev Psiquiatr Clin. 2008;35(1): 21-24.

62. Suter PM, Schutz Y, Jequier E. The effect of ethanol on fat storage in healthy subjects. N Engl J Med. 1992;326(15):983-987.

63. Suter PM, Hasler E, Vetter W. Effects of alcohol on energy metabolism and body weight regulation: is alcohol a risk factor for obesity? Nutr Rev. 1997;55(5):157-171.

64. Suter PM. Is alcohol consumption a risk factor for weight gain and obesity? Crit Rev Clin Lab Sci. 2005;42(3):197227.

65. Silva ABJ, Oliveira AKV, Silva JD, Quintaes KD, SilvaFonseca VA, Aguiar-Nemer A S. Relacao entre consumo de bebidas alcoolicas por universitarias e adiposidade corporal. J Bras Psiquiatr. 2011;60:210-215.

66. Jin L, Huang Y, Bi Y, Zhao L, Xu M, Xu Y, Chen Y, et al. Association between alcohol consumption and metabolic syndrome in 19,215 middle-aged and elderly Chinese. Diabetes Res Clin Pract. 2011;92(3):386-392.

67. Mukamal KJ, Jensen MK, Gronbaek M, Stampfer MJ, Manson JE, Pischon T, Rimm EB. Drinking frequency, mediating biomarkers, and risk of myocardial infarction in women and men. Circulation. 2005;112(10):14061413.

68. Langer RD, Criqui MH, Reed DM. Lipoproteins and blood pressure as biological pathways for effect of moderate alcohol consumption on coronary heart disease. Circulation. 1992;85(3):910-915.

69. Hendriks HF, Veenstra J, Velthuis-te Wierik EJ, Schaafsma G, Kluft C. Effect of moderate dose of alcohol with evening meal on fibrinolytic factors. BMJ. 1994;308(6935):1003-1006.

70. De Oliveira ESER, Foster D, McGee Harper M, Seidman CE, Smith JD, Breslow JL, Brinton EA. Alcohol consumption raises HDL cholesterol levels by increasing the transport rate of apolipoproteins A-I and A-II. Circulation. 2000;102(19):2347-2352.

71. Volcik KA, Ballantyne CM, Fuchs FD, Sharrett AR, Boerwinkle E. Relationship of alcohol consumption and type of alcoholic beverage consumed with plasma lipid levels: differences between Whites and African Americans of the ARIC study. Ann Epidemiol. 2008;18(2):101107.

72. van der Gaag MS, van Tol A, Vermunt SH, Scheek LM, Schaafsma G, Hendriks HF. Alcohol consumption stimulates early steps in reverse cholesterol transport. J Lipid Res. 2001;42(12):2077-2083.

73. Reynolds K, Lewis B, Nolen JD, Kinney GL, Sathya B, He J. Alcohol consumption and risk of stroke: a meta- 
analysis. JAMA. 2003;289(5):579-588.

74. Foppa M, Fuchs FD, Duncan BB. Alcohol and atherosclerosis. Arq Bras Cardiol. 2001;76(2):165-176.

75. Rehm J, Baliunas D, Borges GL, Graham K, Irving H, Kehoe T, Parry CD, et al. The relation between different dimensions of alcohol consumption and burden of disease: an overview. Addiction. 2010;105(5):817-843.

76. Criqui MH, Ringel BL. Does diet or alcohol explain the French paradox? Lancet. 1994;344(8939-8940):17191723.

77. Fillmore KM, Stockwell T, Chikritzhs T, Bostrom A, Kerr W. Moderate alcohol use and reduced mortality risk: systematic error in prospective studies and new hypotheses. Ann Epidemiol. 2007;17(5 Suppl):S16-23.

78. Chen CC, Lin WY, Li CI, Liu CS, Li TC, Chen YT, Yang CW, et al. The association of alcohol consumption with metabolic syndrome and its individual components: the Taichung community health study. Nutr Res. 2012;32(1):24-29.

79. Brewster AC, Lankford HG, Schwartz MG, Sullivan JF. Ethanol and alimentary lipemia. Am J Clin Nutr. 1966;19(4):255-259.

80. Patsch JR, Miesenbock G, Hopferwieser T, Muhlberger V, Knapp E, Dunn JK, Gotto AM, Jr., et al. Relation of triglyceride metabolism and coronary artery disease. Studies in the postprandial state. Arterioscler Thromb. 1992;12(11):1336-1345.

81. Vogel RA, Corretti MC, Plotnick GD. Effect of a single high-fat meal on endothelial function in healthy subjects. Am J Cardiol. 1997;79(3):350-354.

82. Steinberg HO, Tarshoby M, Monestel R, Hook G, Cronin J, Johnson A, Bayazeed B, et al. Elevated circulating free fatty acid levels impair endothelium-dependent vasodilation. J Clin Invest. 1997;100(5):1230-1239.

83. Beilin LJ, Puddey IB. Alcohol and hypertension: an update. Hypertension. 2006;47(6):1035-1038.

84. Klatsky AL. Alcohol and hypertension. Clin Chim Acta. 1996;246(1-2):91-105.

85. Linkola J, Fyhrquist F, Nieminen MM, Weber TH, Tontti $\mathrm{K}$. Renin-aldosterone axis in ethanol intoxication and hangover. Eur J Clin Invest. 1976;6(2):191-194.

86. Puddey IB, Vandongen R, Beilin LJ, Rouse IL. Alcohol stimulation of renin release in man: its relation to the hemodynamic, electrolyte, and sympatho-adrenal responses to drinking. J Clin Endocrinol Metab. 1985;61(1):3742.

87. Sesso HD, Cook NR, Buring JE, Manson JE, Gaziano JM. Alcohol consumption and the risk of hypertension in women and men. Hypertension. 2008;51(4):10801087.

88. Klatsky AL, Friedman GD, Siegelaub AB, Gerard MJ. Alcohol consumption and blood pressure Kaiser-Permanente Multiphasic Health Examination data. N Engl J Med. 1977;296(21):1194-1200.

89. Weissfeld JL, Johnson EH, Brock BM, Hawthorne VM. Sex and age interactions in the association between alcohol and blood pressure. Am J Epidemiol. 1988;128(3):559-569.

90. Marmot MG, Elliott P, Shipley MJ, Dyer AR, Ueshima H, Beevers DG, Stamler R, et al. Alcohol and blood pressure: the INTERSALT study. BMJ. 1994;308(6939):1263-1267.

91. van Leer EM, Seidell JC, Kromhout D. Differences in the association between alcohol consumption and blood pressure by age, gender, and smoking. Epidemiology. 1994;5(6):576-582.

92. Fuchs FD, Chambless LE, Whelton PK, Nieto FJ, Heiss G. Alcohol consumption and the incidence of hypertension: The Atherosclerosis Risk in Communities Study. Hypertension. 2001;37(5):1242-1250.

93. Wakabayashi I. Influence of gender on the association of alcohol drinking with blood pressure. Am J Hypertens. 2008;21(12):1310-1317.

94. Wakabayashi I. Influence of body weight on the relationships of alcohol drinking with blood pressure and serum lipids in women. Prev Med. 2009;49(5):374-379.

95. Stranges S, Wu T, Dorn JM, Freudenheim JL, Muti P, Farinaro E, Russell M, et al. Relationship of alcohol drinking pattern to risk of hypertension: a populationbased study. Hypertension. 2004;44(6):813-819.

96. Xin X, He J, Frontini MG, Ogden LG, Motsamai OI, Whelton PK. Effects of alcohol reduction on blood pressure: a meta-analysis of randomized controlled trials. Hypertension. 2001;38(5):1112-1117. 